American Journal of Biochemistry and Biotechnology 4 (4): 422-424, 2008

ISSN 1553-3468

(C) 2008 Science Publications

\title{
An Optimized Medium for Screening of L-Asparaginase production by Escherichia coli
}

\author{
${ }^{1}$ Younes Ghasemi, ${ }^{1}$ Alireza Ebrahiminezhad, ${ }^{1}$ Sara Rasoul-Amini, ${ }^{2}$ Gholamreza Zarrini, \\ ${ }^{1}$ Mohammad Bagher Ghoshoon, ${ }^{1}$ Mohammad Javad Raee, \\ ${ }^{1}$ Mohammad Hossein Morowvat, ${ }^{1}$ Farshid Kafilzadeh and ${ }^{1}$ Aboozar Kazemi \\ ${ }^{1}$ Faculty of Pharmacy and Pharmaceutical Sciences Research Center, \\ Shiraz University of Medical Sciences, 71345-1583, Shiraz, Iran \\ ${ }^{2}$ Department of Animal Biology, \\ Faculty of Natural Sciences, University of Tabriz, Tabriz, Iran
}

\begin{abstract}
Purified L-asparaginase II from Escherichia coli has been supplied and employed in the acute leukemia and other malignant neoplasms chemotherapy. L-asparaginase II gene (ansB) in $E$. coli is under regulation and certain conditions is needed for expression of this gene. In this investigation ,the various concentrations of modified M9 medium ingredients and various carbon source were tested to optimize the medium for expression and identification of L-asparaginase in E. coli. Finally a semiquantitative plate assay for L-asparaginase producing Escherichia coli is reported.
\end{abstract}

Key words: L-asparaginase, E. coli, medium, ansB

\section{INTRODUCTION}

In 1953 Kidd found that guinea pig serum inhibited a number of transplantable lymphomas in mice and rats as well as certain spontaneous and radiation-induced leukemias in mice. Broome has presented some evidence that the antitumor principle in guinea pig serum is L-asparaginase ${ }^{[1]}$. Deamidation of Lasparagine by extracts of $E$. coli was first reported in $1957^{[2]}$. Later, Mashburn and Wriston observed that Lasparaginase (L-asparagine amidohydrolase, Enzyme Commission 3.5.1.1) purified from cell extract of $E$. coli has an antitumor activity similar to that of guinea pig serum ${ }^{[3]}$. Although other microorganisms such as Aerobacter, Bacillus, Erwinia, Pseudomonas, Serratia, Xanthomonas, Photobacterium ${ }^{[4]}$, Streptomyces ${ }^{[5]}$, Proteus $^{[3]}$, Vibrio $^{[6]}$ and Aspergillus ${ }^{[7]}$ have a potential for asparaginase production, purified enzyme from $E$. coli has been supplied and employed in the clinical application for acute leukemia and other malignant neoplasms in human. L-asparaginase belongs to an amidase group that hydrolyses the amide bond in Lasparagine to aspartic acid and ammonia. Unlike the normal cells, neoplastic cells cannot synthesize Lasparagine due the absence of L-asparagine synthetase. Therefore, they obtain the required asparagine from circulating pools. For this reason, intravenous injection of free enzyme results in selective neoplastic cell death, directly by the depletion of circulating asparagine levels or indirectly from some other metabolite of the asparaginase reaction $^{[7-9]}$.

$E$. coli has two isozymes of L-asparaginase ${ }^{[10]}, \mathrm{L}-$ asparaginase I (AnsA) which is found in the cytoplasm and has a low affinity for L-asparagine $(\mathrm{EC} 1 ; \mathrm{Km}=3.5$ $\mathrm{mM})$ and L-asparaginase II $(A n s B)$ that is a periplasmic enzyme used in the treatment of acute lymphoblastic leukemia and in contrast, it is a high-affinity enzyme (EC2; Km = $10 \mathrm{pM})$. AnsA is thought to be constitutively produced but ans $B$ gene expression is changed by aeration, carbon source and variation of available amino acids ${ }^{[1,2,11]}$. In this investigation, an optimized medium for semi-quantitative plate assay and screening of L-asparaginase producing $E$. coli is reported based on modified M-9 medium ${ }^{[12]}$. In this medium, L-asparagine is used as the sole nitrogen source. The production of L-asparaginase by E. coli leads to ammonia formation and increase in $\mathrm{pH}$ of the medium. A pH indicator (phenol red) makes medium pink around the colonies producing L-asparaginase.

\section{MATERIALS AND METHODS}

Isolation and identification of $\boldsymbol{E}$. coli: Environmental samples were collected from waste water and the Khoshk River, Shiraz, Iran (in February 2008). Clinical

Corresponding Author: Younes Ghasemi, Faculty of Pharmacy and Pharmaceutical Sciences Research Center, Shiraz University of Medical Sciences, Shiraz, Iran Tel: +98-711-2425305 Fax: +98-711-2426070 
Table 1: Medium ingredients and their tested concentrations for optimization of the medium for L-asparaginase producing E. coli

\begin{tabular}{lllll}
\hline Ingredients & \multicolumn{4}{l}{ Concentrations } \\
\hline Glucose $\left(\mathrm{g} \mathrm{L}^{-1}\right)$ & 10.00 & 5.00 & 1.00 & 0.00 \\
Maltose $\left(\mathrm{g} \mathrm{L}^{-1}\right)$ & 10.00 & 5.00 & 1.00 & 0.00 \\
Fructose $\left(\mathrm{g} \mathrm{L}^{-1}\right)$ & 10.00 & 5.00 & 1.00 & 0.00 \\
Galactose $\left(\mathrm{g} \mathrm{L}^{-1}\right)$ & 10.00 & 5.00 & 1.00 & 0.00 \\
$\mathrm{~L}-$ asparagine $\left(\mathrm{g} \mathrm{L}^{-1}\right)$ & 10.00 & 8.00 & 6.00 & 4.00 \\
$\mathrm{KH}_{2} \mathrm{PO}_{4}\left(\mathrm{~g} \mathrm{~L}^{-1}\right)$ & 3.00 & 2.00 & 1.00 & 0.75 \\
$1 \mathrm{M} \mathrm{MgSO}_{4}\left(\mathrm{ml} \mathrm{L}^{-1}\right)$ & 1.50 & 1.00 & 0.50 & 0.00 \\
$0.1 \mathrm{M} \mathrm{CaCl}_{2} .2 \mathrm{H}_{2} \mathrm{O}\left(\mathrm{ml} \mathrm{L}^{-1}\right)$ & 1.50 & 1.00 & 0.50 & 0.00 \\
Phenol red solution $2.5 \%\left(\mathrm{ml} \mathrm{L}^{-1}\right)$ & 4.00 & 3.00 & 2.00 & 1.00 \\
\hline
\end{tabular}

samples were obtained from urine and stool samples sent to medical laboratory of the Namazi Hospital, Shiraz, Iran. The samples were inoculated on EMB (eosin-methylene blue agar) and MacConkey's agar. Lactose positive colonies (with pink center or metallic shine on EMB) were tested by IMViC test (Indole, MR, VP and Citrate). A total of 130 isolates of $E$. coli were isolated (33 from waste water, 15 from the Khoshk River, 47 from urine samples and 35 from stool samples).

Optimization of medium: The various concentrations of $\mathrm{Na}_{2} \mathrm{HPO}_{4} .2 \mathrm{H}_{2} \mathrm{O}, \quad \mathrm{KH}_{2} \mathrm{PO}_{4}, \mathrm{NaCl}, \quad$ L-asparagine, $\mathrm{MgSO}_{4} \cdot 7 \mathrm{H}_{2} \mathrm{O}, \mathrm{CaCl}_{2} .2 \mathrm{H}_{2} \mathrm{O}$, carbon sources and phenol red were tested as ingredients of medium; one factor was changed while others were constant (Table 1). The $\mathrm{pH}$ of the media was adjusted at 7.0.

Stock solution of the phenol red was prepared (2.5\% in ethanol, $\mathrm{pH} 7.0$ ), filtered by $0.2 \mu \mathrm{m}$ cellulose filter and added to autoclaved media. E. coli isolates were inoculated on the prepared plates and incubated at $37^{\circ} \mathrm{C}$ for $48 \mathrm{~h}$. The Modified M9 medium was used as blank. After incubation, L-asparaginase activity were reported as (-), trace or (+) based upon intensity of produced pink color and pink zone diameter.

\section{RESULTS}

Studies with different concentrations of ingredients revealed that the most appropriate concentrations in 1 liter of medium are $\mathrm{KH}_{2} \mathrm{PO}_{4}(0.75 \mathrm{~g}), \mathrm{NaCl}(0.5 \mathrm{~g})$, Lasparagine ( $10 \mathrm{~g})$, Maltose (1 g), agar (17 g) and phenol red $(0.05 \mathrm{~g})$. On optimized medium with above concentrations among the 130 isolates of E. coli, 35 isolates produced trace pink zone and 8 isolates produced (+) zone (Fig. 1), while only 4 trace zones were produced on modified M9 medium (Table 2).

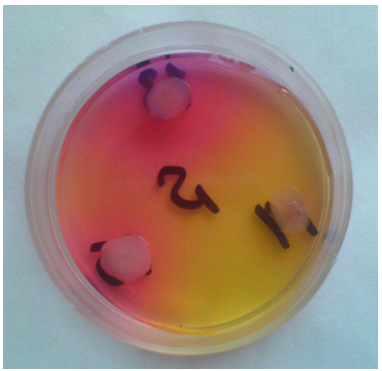

Fig. 1: Pink zone production by L-asparaginase producing $E$. coli on optimized medium

Table 2: Intensity of pink halo production by isolates of E. coli on modified M9 and optimized medium

\begin{tabular}{llllllll}
\hline & $\begin{array}{l}\text { Total } \\
\text { Isolation } \\
\text { isolates }\end{array}$ & $\begin{array}{l}\text { Pink zone intensity on the } \\
\text { modified M9 medium }\end{array}$ & \multicolumn{2}{l}{$\begin{array}{l}\text { Pink zone intensity on the } \\
\text { optimized medium }\end{array}$} \\
\hline $\begin{array}{l}\text { Nource } \\
\text { River }\end{array}$ & 15 & Negative & Trace & Positive & Negatives & Trace & Positive \\
Waste & 33 & 33 & 0 & 0 & 12 & 2 & 1 \\
water & & & 0 & 0 & 30 & 3 & 0 \\
Urine & 47 & 44 & 3 & 0 & 24 & 19 & 4 \\
Stool & 35 & 34 & 1 & 0 & 21 & 11 & 3 \\
\hline
\end{tabular}

\section{DISCUSSION}

The ans $B$ gene of $E$. coli is regulated by catabolite activator protein (CAP; also called cyclic AMP receptor protein or CRP $)^{[1,2,11]}$. The low level of intracellular glucose results in a high level of cAMP, which means high cAMP-CAP complexes. cAMP-CAP binds to a specific site on the DNA that is located adjacent to the promoter for the genes regulated by CAP. The -10 and 35 motifs in the promoter sequence for such genes are not a perfect match to the consensus sequence for $\sigma^{70}$ promoters. cAMP-CAP bound to the CAP binding site increases the binding of $\sigma^{70}$ RNA polymerase to the promoter and increases gene expression ${ }^{[13]}$. Therefore, glucose is an inhibitor for $a n s B$ gene. We changed the carbon source of medium from glucose, to disaccharide for reduction in the level of intracellular glucose and more $A n s B$ production; maltose was the best. Also, in contrast to modified $\mathrm{M} 9$ medium, $\mathrm{Na}_{2} \mathrm{HPO}_{4}$ has been eliminated to reduce bufferic properties of medium and little ammonia identification. The optimum concentration of phenol red in the medium is $0.05 \mathrm{mg}$ $\mathrm{L}^{-1}$ which keeps the colour yellow for a better identification of colour change to pink for trace amounts of L-asparaginase. High concentrations of phenol red giving the colour of medium dark red make difficult to identify the pink zone. The observed results encourage us to continue further screening for Lasparaginase production in the other microorganisms (Bacteria and Fungi) on our optimized medium. 
Am. J. Biochem. \& Biotech., 4 (4): 422-424, 2008

\section{CONCLUSION}

The optimized medium is a sensitive medium for L-asparaginase detection and trace amounts of produced enzyme by E. coli. This medium can be used as proper medium for other L-asparaginase producingmicroorganisms.

\section{REFERENCES}

1. Roberts, J., M.D. Prager and N. Bachynsky, 1966. The antitumor activity of Escherichia coli LAsparaginase. Cancer Res., 26: 2213-2217. http://cancerres.aacrjournals.org/cgi/reprint/26/10/2213.

2. Cedar, H. and J.H. Schwartz, 1968. Production of L-Asparaginase II by Escherichia coli. J. Bacteriol., 96: 2043-2048. http://www.pubmedcentral.nih.gov/picrender.fcgi? artid $=252556 \&$ blobtype $=$ pdf.

3. Tosa, T., R. Sano, K. Yamamota, M. Nakamura, K. Ando and I. Chibata, 1971. L-Asparaginase from Proteus vulgaris. Applied Environ. Microbiol., 22: 387-392. http://www.pubmedcentral.nih.gov/picrender.fcgi? artid $=376319 \&$ blobtype $=$ pdf.

4. Peterson, R.E. and A. Ciegler, 1969. Lasparaginase production by various bacteria. Applied Environ. Microbiol., 17: 929-930. http://www.pubmedcentral.nih.gov/articlerender.fc gi artid $=377846$.

5. Dejong, P.J., 1972. L-Asparaginase production by Streptomyces griseus. Applied Environ. Microbiol., 23:1163-1164.

http://www.pubmedcentral.nih.gov/articlerender.fc gi?tool=pubmed $\&$ pubmedid $=4626231$.

6. Kafkewitz D. and D. Goodman, 1974. L-Asparaginase production by the rumen anaerobe Vibrio succinogenes. Applied Environ. Microbiol., 27: 206-209. http://www.pubmedcentral.nih.gov/articlerender.fc gi artid=379995.
7. Sarquis, M.I., E.M. Oliveira, A.S. Santos and G.L. Costa, 2004. Production of L-asparaginase by filamentous fungi. Mem. Inst. Oswaldo Cruz., 99: 489-492. http://www.scielo.br/pdf/mioc/v99n5/v99n5a05.pdf.

8. Swain, A.L., M. Jaskolski, D. Housset, J.K. Mohana Rao and A. Wlodawert, 1993. Crystal structure of Escherichia coli L-asparaginase, an enzyme used in cancer therapy. Biochemistry, 90: 1474-1478. http://www.pnas.org/content/90/4/1474.full.pdf+html.

9. Kozak, M. and S. Jurgab, 2002. A comparison between the crystal and solution structures of Escherichia coli asparaginase II. Acta Biochim. Pol., 49: 509-513. http://www.actabp.pl/pdf/2_2002/509513s.pdf.

10. Schwartz, J.H., J.Y. Reeves and J.D. Broome, 1966. Two L-Asparaginase from E. coli and their action against tumors. Biochemistry, 26: 1516-1519. http://www.pubmedcentral.nih.gov/articlerender.fc gi artid=220017.

11. Jennings, M.P. and I.R. Beacham, 1990. Analysis of the Escherichia coli gene encoding L-Asparaginase II, ans $B$ and Its regulation by cyclic AMP receptor and FNR proteins. J. Bacteriol., 172: 1491-1498. http://www.pubmedcentral.nih.gov/articlerender.fcgi? artid $=208625$.

12. Gulati, R., R.K. Saxena and R. Gupta, 1997. A rapid plate assay for screening L-asparaginase producing micro-organisms. Lett. Applied Microbiol., 24: 23-26. http://www3.interscience.wiley.com/cgibin/fulltext/119154370/PDFSTART.

13. Trun, N. and J. Trempy, 2004. Fundamental Bacterial Genetics. 1st Edn., Published by Blackwell Publishing, Blackwell Science Ltd., ISBN: 10: 0632044489, pp: 304. 